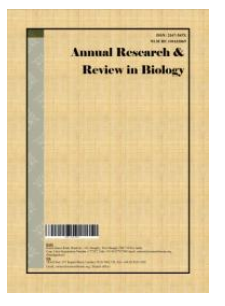

\title{
Diet of the Silky Shark Carcharhinus falciformis (Müller \& Henle, 1839) in Waters off Côte d'Ivoire (West Africa)
}

\author{
Koua Clément N'Gouan ${ }^{1}$, Kouadio Justin Konan $^{2^{*}}$ and Oi Edia Edia ${ }^{1}$ \\ ${ }^{1}$ Laboratoire d'Environnement et de Biologie Aquatique, UFR-SGE, Université Nangui Abrogoua, 02 \\ BP 801 Abidjan 02, Côte d'Ivoire. \\ ${ }^{2}$ Centre de Recherches Océanologiques, BPV 18, Abidjan, Côte d'Ivoire.
}

\begin{abstract}
Authors' contributions
This work was carried out in collaboration among all authors. Authors KCNG and KJK designed the research, analysed the data and prepared the manuscript. Author OEE proof read the manuscript and assisted in supervisory role.All authors read and approved the final manuscript.

Article Information

DOI: 10.9734/ARRB/2021/v36i830411 Editor(s):

(1) Dr. Bechan Sharma, University of Allahabad, India.

Reviewers:

(1) Nor Anis Nadhirah Bt Md Nasir, Universiti Malaysia Perlis, Malaysia.

(2) Yahya Shafiei Bavil Oliaei, Islamic Azad University, Iran. Complete Peer review History: https://www.sdiarticle4.com/review-history/71510
\end{abstract}

Original Research Article

Received 23 May 2021

Accepted 28 July 2021

Published 12 August 2021

\section{ABSTRACT}

Aims: This study was to establish the feeding habits of silky shark Carcharhinus falciformis in waters off Côte d'Ivoire.

Study design: All stomachs of the specimens were collected using a standard method and analysed at laboratory.

Place and Duration of Study: The study of the diet of $C$. falciformis was carried out at the laboratory of the Oceanological Research Centre (ORC) between April 2019 and August 2020.

Methodology: To carry out this study, measurements and extractions of the stomachs of silky sharks were performed using a tape measure and dissection kit. Diet was described using the Index of Relative Importance (\%IRI). The food overlap between sexes, size groups and marine seasons were analysed using the Morisita index.

Results: A total of 265 specimens ranging in size from 79 to $254 \mathrm{~cm}$ total length were used. Of the stomachs examined, 163 individuals had food contents (61.51\%), whilst 102 were empty (38.49\%). The results indicated that silky shark has epipelagic and mesobathypelagic feeding habits, preying 
upon a wide number of prey taxa (33 species) but with a diet dominated by teleost fishes, especially Thunnus albacares $(60.62 \% \mathrm{IRI})$ and Katsuwonus pelamis $(33.18 \% \mathrm{IRI})$. The Morisita index and the Spearman rank correlation coefficient showed similarity of the diet between sexes $(C \lambda>0.60 ; R s=$ 0.776 and $p=0.001$ and marine seasons $(C \lambda>0.60 ; \mathrm{Rs}=0.658$ and $p=0.001)$. The juveniles and adults did not show any overlap. The Amundsen graphical (Fig. 3) analysis suggested that silky shark displays specialist feeding behaviour in this area.

Conclusion: Diet consisted mainly of $T$. albacares and $K$. pelamis, the proportions of which varied according to size and marine seasons. Carcharhinus falciformis is considered to be a specialist predator.

Keywords: Carcharhinus falciformis; feeding habits; shark; waters off Côte d'Ivoire; West Africa.

\section{INTRODUCTION}

The silky shark Carcharhinus falciformis (Müller and Henle 1839) is one of the common epipelagic sharks found throughout tropical and subtropical waters. This species, as most sharks are regarded as predators playing an important role within marine ecosystems, maintaining the balance of food webs, through the regulation of prey populations of lower trophic levels $[1,2]$. It is occasionally occurring inshore where the water is as shallow as $18 \mathrm{~m}$; in the open ocean it occurs from the surface down to at least $500 \mathrm{~m}$ depth [3]. The silky shark is one of the shark species most frequently caught as a by-catch in the longline and gillnet fisheries targeting the swordfish and/or tunas in the North and southwest Atlantic [4]. In recent years, their abundance has declined drastically [5]. In 2007, the IUCN Red List of Threatened Species considered, the silky shark as globally near threatened, and vulnerable in some areas, due to continued decline in populations around the world. Given their role, the disappearance of these predators from marine ecosystems may have consequences for their functioning and resilience $[1,2]$.

Studies on the trophic ecology, diet composition and trophic level of sharks shed light on their life histories, roles in marine ecosystems and species distributions as well as energy flows, and the impact of predation by different species [6]. Information regarding important feeding and breeding areas identified by such studies are used in conjunction with other biological studies to develop appropriate strategies for the conservation and management of shark species. Food preference of predatory fish is complex and influenced by many factors, such as available prey and their mobility, prey abundance and size, seasonal changes and environmental factors [7]. Determining the trophic relationships among species assists us to understand their community organization and effect on ecosystem [8]. Food ecology of $C$. falciformis is restricted to subtropical and tropical inshore areas of the Indian and Pacific Oceans [7,9,10,11]. These works indicated a food spectrum including mainly of bony fishes, cephalopods and crustacea. Despite the importance of the silky shark as both top predator and component of the bycatch, no information can be found on its feeding habits in the central eastern Atlantic and specifically off the coastal waters of Côte d'lvoire. Therefore, this study aims to describe and quantify the diet of $C$. falciformis based on stomach content analysis and assess possible intraspecific dietary overlap according to sexes, size groups and seasons.

\section{MATERIALS AND METHODS}

\subsection{Sampling and Laboratory Processing}

Samples were obtained monthly at the fishing harbour of Abidjan (Côte d'Ivoire), from catches of the artisanal driftnet fishery operating between latitudes $4^{\circ} \mathrm{N}$ and $5^{\circ} \mathrm{N}$ and longitudes $2.30^{\circ} \mathrm{W}$ and $8^{\circ} \mathrm{W}$ from April 2019 to August 2020 (Fig 1). The Duration of the tide was 4-5 days and the fishing activities take place at night. Fishermen used baited hooks in association with driftnet to attract sharks. Before collecting the stomach samples, each individual was sexed and the total length (TL) was measured to the nearest $0.1 \mathrm{~cm}$ using a measuring tape. Stomach samples were removed and kept frozen at $-20^{\circ} \mathrm{C}$ for further analysis in the biology laboratory of the Oceanological Research Centre, Abidjan.

Laboratory procedures consisted of thawing the stomachs, separating the remaining food into different categories of prey, identifying the prey to the lowest taxonomic level possible, 
classifying the prey by digestion state according to the following classification (1) fresh = prey that could be identified by external characteristics such as skin, scales, fins because they were undigested; (2) intermediate = prey that had lost some external characteristics (skin, scales); (3) advanced $=$ well digested prey that showed the skeleton (fish) ; and (4) digested = fish skeleton or beaks from cephalopods) [7] (Fig 2), weighing the prey to the nearest $0.01 \mathrm{~g}$, and enumerating the prey when individuals were recognizable. Fish categories were identified using the identification guides of [12], [13] and [14]. For cephalopods, all parts and lower beaks of stomachs were used for prey identification by comparison with field and beak identification guides as well as personal cephalopod lower beak reference collections $[15,16]$. Whenever the identification based on morphological characteristics was impossible, measurements achieved on beaks as the lower hood length (LHL) and lower rostrum length (LRL) or upper hood length (UHL) and upper rostral length (URL) were used to reconstruct the mantle length (ML) and total weight, following regression equations between the biomass and above sizes of beaks $[17,15]$. All remaining foods or hard parts of preys unidentified were classified into category of undetermined preys. Fish and other stomach contents with knife cuts were considered as bait and eliminated in data processing.

\subsection{Data Analysis}

Feeding was assessed using vacuity index as follow:
$\% \mathrm{VI}=\frac{\text { Number of empty stomachs }}{\text { Total number of stomachs }} \times 100$

The contribution of each prey item to the diet was evaluated using the Index of Relative Importance (IRI). This index was described by [18] and subsequently converted into a percentage (\%IRI) by [19]:

$$
\begin{aligned}
& \mathrm{IRI}=\% \mathrm{~F} \times(\% \mathrm{~N}+\% \mathrm{~W}) \\
& \% \mathrm{IRI}=\frac{\mathrm{IRI}}{\sum \mathrm{IRI}} \times 100
\end{aligned}
$$

where, $\% \mathrm{~N}$ is the number and $\% \mathrm{~W}$ is the wet weight of each food item, expressed as the percentage of the total of each variable for all prey items in the stomach contents; and \%F is the percentage frequency of occurrence of each food item (presence-absence) in all stomachs that contained food. The classification of prey items followed the method of [20] Rosecchi and Nouaze (1987). For this purpose, preys were first sorted in decreasing order of importance according to cumulative \%IRI was calculated. The first single item, or group of items, for which cumulative $\%$ IRI was $\geq 50 \%$ was regarded as the preferred food. The \%IRI values of other important prey items were then added to that of the preferred food until the \%IRI reached $75 \%$, and these were regarded as secondary prey. Food items between an \%IRI of 75 and $100 \%$ were regarded as incidental prey. The IRI was compared among sexes, maturity groups and seasons.

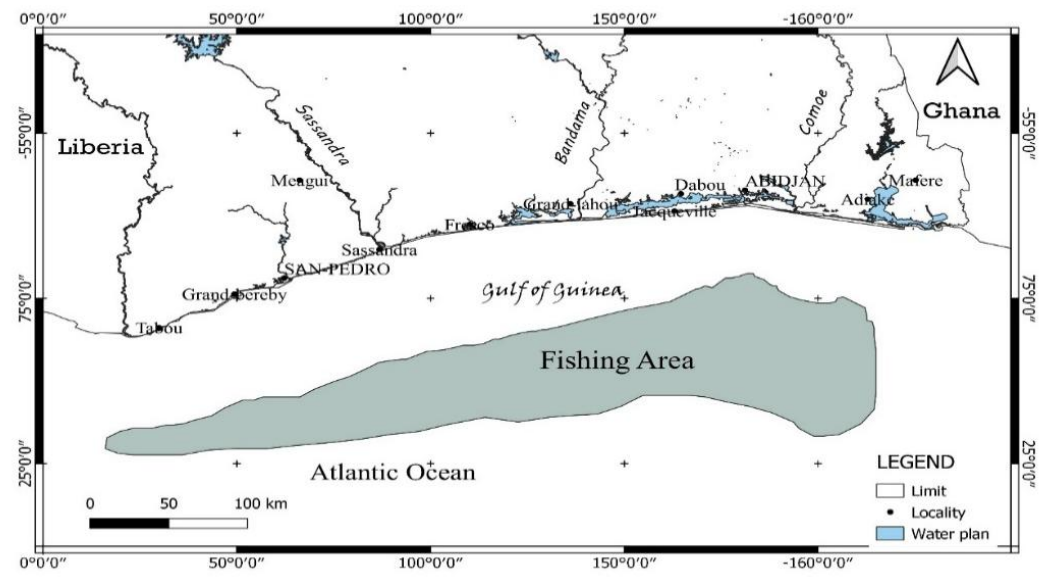

Fig. 1. Study map showing landing and sampling sites for silky shark, Carcharhinus falciformis 
The food Overlaps between sexes, size groups and marine seasons were analysed using the Morisita index [21]. Values between 0 and 0.29 indicate a lower overlap, between 0.30 and 0.59 a medium overlap, and values over 0.60 show a higher overlap. Its formula is as follow.

$$
\mathrm{C} \lambda=\frac{2 \sum_{\mathrm{i}=1}^{\mathrm{n}}\left(\mathrm{P}_{\mathrm{ix}} \times \mathrm{P}_{\mathrm{iy}}\right)}{\left(\sum_{\mathrm{i}=1}^{\mathrm{n}} \mathrm{P}_{\mathrm{ix}}^{2}+\sum_{\mathrm{i}=1}^{\mathrm{n}} \mathrm{P}_{\mathrm{iy}}^{2}\right)}
$$

Where $\mathrm{C}_{\lambda}$ is the Morisita-Horn index, $\mathrm{P}_{\mathrm{ix}}$ and $\mathrm{P}_{\mathrm{iy}}$ are proportions (based on \% IRI) of a prey $i$ consumed by the predators $x$ and $y$ respectively, following the sex and marine seasons. To study diet variation with fish size, specimens were divided into two categories according to the maturity size of [22] (immature TL $<180$ and mature: $T L>L_{50}$, where $L_{50}$ is the size at maturity).

Feeding pattern was assessed using the graphical analysis propose by [23] which provides information about prey importance and the predator feeding strategy by comparing a two-dimensional graph of prey-specific abundance $\left(\% \mathrm{~S}_{\mathrm{i}}\right)$ plotted versus frequency of occurrence $\% \mathrm{O}$. The prey-specific abundance was determined through following formula:

$$
\% \mathrm{~S}_{\mathrm{i}}=\left(\sum \mathrm{P}_{\mathrm{i}} / \sum \mathrm{P}\right) \times 100
$$

Where $P_{i}=$ weight of the prey $i$ and $P=$ total weight of preys into stomach containing prey $i$.

The Spearman's rank correlation coefficient (Rs) was used to test the similarity of the diet according to sexes, seasons and size groups. This test was performed using the software statistica 7.1.

\section{RESULTS AND DISCUSSION}

\subsection{Results}

\subsubsection{Diet composition}

A total of 265 specimens of which 128 males and 137 females ranged in size from 79 to $254 \mathrm{~cm}$, LT were analysed. Of the stomachs examined, 163 individuals had food contents $(61.51 \%)$, whilst 102 were empty (38.49\%). Some specimens with regurgitated stomachs $(13.92 \%)$ were found in catches. Several fishes were in an intermediate (state 2), and advanced digestive state (state 3 ) in the stomachs of sharks, whereas cephalopods were in an advanced state of digestion (state 4). Taxonomic analyses included 21 fish species and 12 cephalopod species belonging respectively to 12 and 10 families (Table 1). Teleost fishes were the dominant prey group in the stomach contents analysed, contributing to the overall diet of 98.61 $\% \mathrm{IRI}$, whereas cephalopods were considered as incidental prey items (1.39 \%IRI). Among teleost fishes, the most important prey items were Scombridae family represented by Thunnus albacares (60.62 \% IRI) and Katsuwonus pelamis (33.18\% \% IRI). The other teleost fishes were minor components $(4.77 \% \mathrm{IRI})$. In cephalopod species, Loligo vulgaris (0.96 \% IRI), Taningia danae (0.11 $\% \mathrm{IRI})$ and Sepia officinalis (0.09\%IRI) were more consumed.
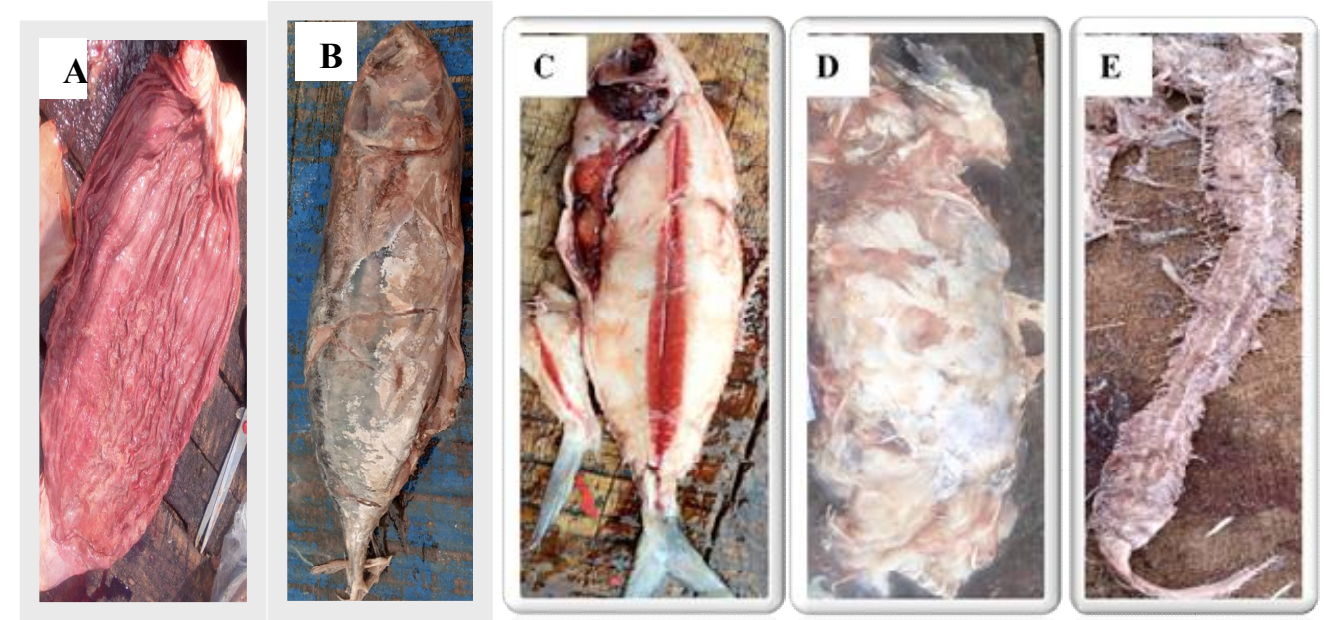

Fig. 2. Images showing (A) empty stomach and the state of digestion $(B=$ state $1 ; C=$ state 2; $D=$ state 3; $E$ = state 4) 
Table 1. Prey composition of the silky shark Carcharhinus falciformis caught in coastal waters of Côte d'Ivoire, with their occurrence percentage $(\% \mathrm{O})$, numerical percentage $(\% \mathrm{~N})$, weight percentage $(\% \mathrm{~W})$, index of relative importance (\% IRI) and specific abundance index (\% Si)

\begin{tabular}{|c|c|c|c|c|c|c|}
\hline \multirow{3}{*}{ Families } & \multirow[b]{2}{*}{ Species } & \multicolumn{5}{|c|}{ Global } \\
\hline & & $\% 0$ & $\% \mathbf{W}$ & $\% \mathrm{~N}$ & $\%$ IRI & $\% \mathrm{Si}$ \\
\hline & Teleost fishes & 89.53 & 86.21 & 85.39 & 98.61 & - \\
\hline Bramidae & Brama brama & 0.58 & 0.34 & 1.37 & 0.02 & 15.69 \\
\hline \multirow[t]{7}{*}{ Scombridae } & Acanthocybium solandri & 0.58 & 0.68 & 0.46 & 0.02 & 25.68 \\
\hline & Katsuwonus pelamis & 26.28 & 23.07 & 26.48 & 33.18 & 73.95 \\
\hline & Thunnus albacares & 29.07 & 41.65 & 24.20 & 60.62 & 93.84 \\
\hline & Euthynnus alletteratus & 1.74 & 1.32 & 1.37 & 0.11 & 26.58 \\
\hline & Auxis thazard & 2.33 & 0.85 & 2.28 & 0.11 & 84.99 \\
\hline & Sarda sarda & 6.98 & 4.89 & 6.85 & 1.85 & 58.89 \\
\hline & Unidentified tunas & 7.56 & 4.60 & 8.22 & 1.98 & 79.67 \\
\hline Lobotidae & Lobotes surinamensis & 0.58 & 0.24 & 0.46 & 0.01 & 24.35 \\
\hline \multirow[t]{4}{*}{ Carangidae } & Seriola carpenteri & 2.91 & 0.73 & 2.28 & 0.10 & 86.93 \\
\hline & Caranx crysos & 1.74 & 1.11 & 1.83 & 0.11 & 81.44 \\
\hline & Caranx hippos & 1.16 & 1.19 & 1.83 & 0.10 & 54.57 \\
\hline & Trachurus trachurus & 0.58 & 0.40 & 0.46 & 0.01 & 31.00 \\
\hline Echeneidea & Remora remora & 0.58 & 0.24 & 0.91 & 0.01 & 22.12 \\
\hline Sparidae & Pagellus bellottii & 0.58 & 0.51 & 0.46 & 0.01 & 21.59 \\
\hline Trichiuridae & Trichiurus lepturus & 0.58 & 0.34 & 0.46 & 0.01 & 29.45 \\
\hline Sphyraenidae & Sphyraena guachancho & 0.58 & 0.39 & 0.91 & 0.02 & 43.64 \\
\hline Tetraodontidae & $\begin{array}{l}\text { Lagocephalus } \\
\text { lagoceohalus }\end{array}$ & 0.58 & 0.32 & 0.46 & 0.01 & 10.05 \\
\hline Diodontidae & Diodon holocanthus & 1.74 & 0.55 & 1.37 & 0.05 & 49.82 \\
\hline Dactylopteridae & Dactylopterus volitans & 0.58 & 0.59 & 0.91 & 0.02 & 46.88 \\
\hline Albulidae & Elagatis bipinulata & $\begin{array}{l}2.33 \\
10.47\end{array}$ & $\begin{array}{l}2.33 \\
13.66\end{array}$ & $\begin{array}{l}1.83 \\
1461\end{array}$ & $\begin{array}{l}0.26 \\
1.39\end{array}$ & 43.30 \\
\hline Loliginidae & Loligo vulgaris & 2.91 & 4.20 & 5.48 & 0.96 & 57.33 \\
\hline Lepidoteuthidae & Lepidoteuthis grimaldii & 0.58 & 1.63 & 0.91 & 0.06 & 36.81 \\
\hline \multirow{2}{*}{ Ommastrephidae } & Martialia hyadesi & 0.58 & 1.36 & 0.91 & 0.06 & 44.39 \\
\hline & Eucleoteuthis luminosa & 0.58 & 0.24 & 0.46 & 0.01 & 14.88 \\
\hline Octopoteuthidae & Taningia danae & 0.58 & 2.76 & 0.91 & 0.11 & 100.00 \\
\hline Chiroteuthidae & Chiroteuthis veranyi & 0.58 & 0.30 & 0.46 & 0.01 & 0.66 \\
\hline Ancistrocheiridae & Ancistrocherus lesueuri & 0.58 & 0.25 & 0.46 & 0.01 & 50.57 \\
\hline Cranchiidae & Teuthowenia pellucida & 0.58 & 0.31 & 0.46 & 0.01 & 100 \\
\hline \multirow[t]{2}{*}{ Histioteuthidae } & Histioteuthis miranda & 0.58 & 0.52 & 1.37 & 0.02 & 88.38 \\
\hline & Histioteuthis atlantica & 0.58 & 0.49 & 1.37 & 0.03 & 85.12 \\
\hline Onychoteuthidae & Onychoteuthis banksii & 0.58 & 0.69 & 0.46 & 0.02 & 1.39 \\
\hline Sepiidae & Sepia officinalis & 1.74 & 1.06 & 1.37 & 0.09 & 75.21 \\
\hline
\end{tabular}

3.1.2 Diet interactions between sexes, size groups and marine seasons

The trophic spectrum of both females and males consisted of teleost fishes and cephalopods (Fig 3). The most important prey species for females and males were $T$. albacares (52.95 and $55.43 \% \mathrm{IRI}$, respectively), K. pelamis (38.79 and $34.58 \% \mathrm{IRI})$ and L. vulgaris (1.34 and $2.03 \% \mathrm{IRI})$. Males also consumed Sarda sarda $(1.18 \% \mathrm{IRI})$, Elagatis bipinulata (0.89\% \% RI), Diodon holocanthus (0.49\% \% RI) and Caranx crysos $(0.43 \% \mathrm{IRI})$.
Regarding size groups, immatures mainly fed on K. pelamis $(61.12 \% \mathrm{IRI}), T$. albacares $(29.93 \%$ IRI), S. sarda (2.24 \% IRI) and L. vulgaris (1.56 $\%(\mathrm{RI})$. In Matures, the main prey items were $T$. albacares $(88.33 \% \mathrm{IRI})$, K. pelamis $(4.17 \% \mathrm{IRI})$, L. vulgaris $(3.13 \% \mathrm{IRI}), T$. danae $(2.95 \% \mathrm{IRI})$ and E. bipinulata $(1.43 \% \mathrm{IRI})$.

Concerning seasons, prey diversity for silky shark collected was highest in cold season (Fig 3 ). The main prey items in diets were similar in both seasons but the proportions varied greatly between the cold and warm seasons. In cold season, the diet was exclusively dominated by $T$. 
albacares (42.91 \%IRI), K. pelamis (48.83 \%IRI) whereas S. sarda (3.81\%IRI), L. vulgaris (1.14 $\% \mathrm{IRI})$, Taningia danae (0.09\%IRI), Seriola carpenteri (0.32 \% IRI) and Caranx crysos (0.18 $\%$ IRI) were eaten incidentally. In warm season, the diet was also dominated by K. pelamis $(24.88$ $\%$ IRI) and $T$. albacares (34.71 \%IRI) but their quantity decreases in favour of $L$. vulgaris $(17.79$ \%IRI), A. thazard (4.42 \%IRI) and E. bipinulata (3.74 \%IRI).
The Morisita-Horn index indicated a high trophic overlap between sexes $(\mathrm{C} \lambda=0.997)$ and seasons $(C \lambda=0.658)$, whereas there was medium overlap between size groups $(\mathrm{C} \lambda=$ 0.466). The Spearman's tests were significant between sexes (Rs $=0.776$; $p=0.001)$ and seasons (Rs $=0.950 ; p=0.001$ ) but not according size groups (Rs $=0.8$; $p=0.2$ ).

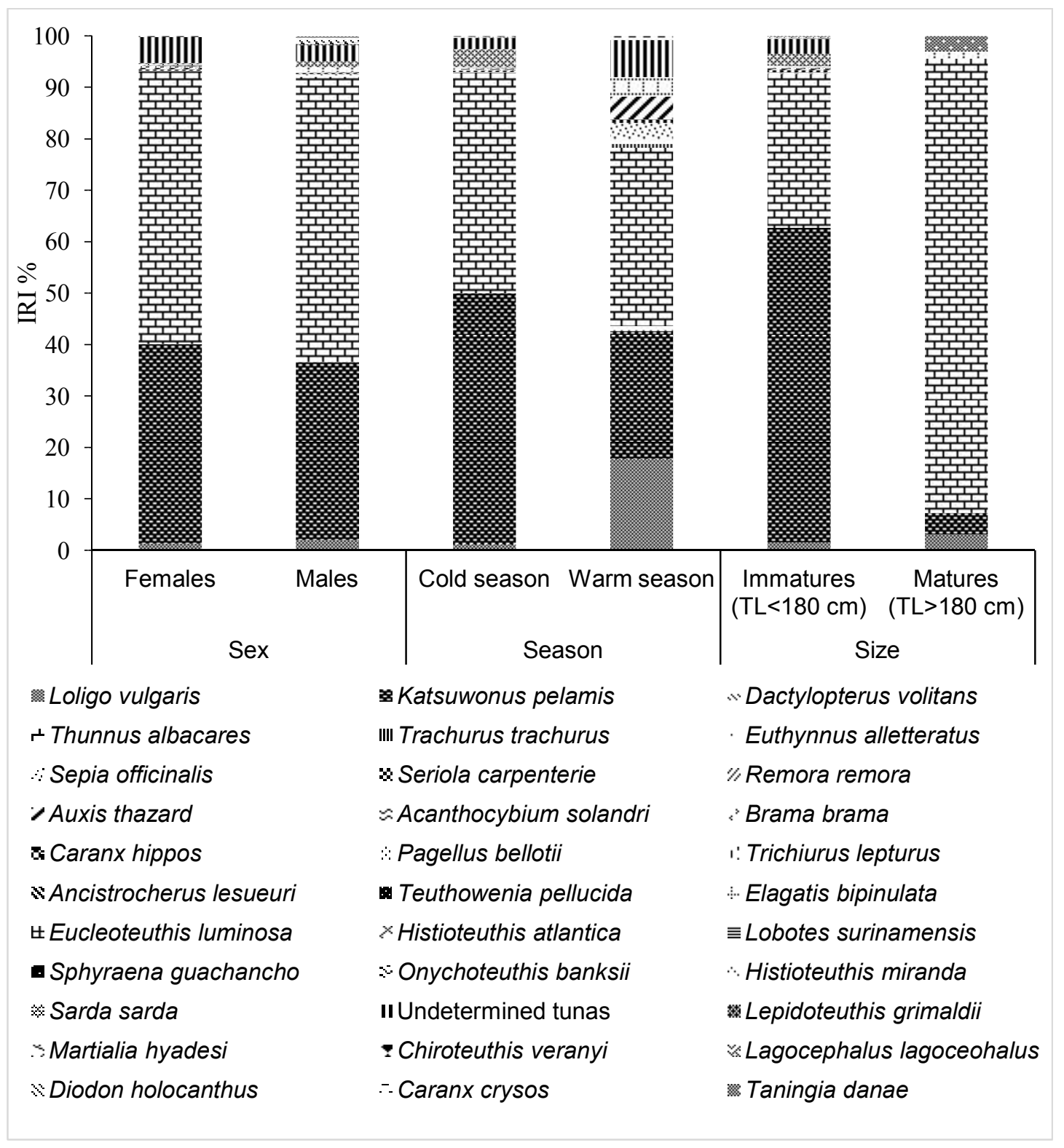

Fig. 3. Index of Relative Importance (\%IRI) for prey items of silky shark according sex (males and females), size (TL < 182; TL > 180) and marine season (cold and warm seasons) in coastal waters of Côte d'Ivoire 


\subsubsection{Food strategy}

The Amundsen graphical analysis suggests that silky shark displays specialist feeding behaviour that focuses on $T$. albacares and K. pelamis (Fig 4, upper and left side) followed by $S$. sarda. Other teleost fishes namely Lobotes surinamensis, Brama brama, S. carpenteri, Auxis thazard, Acanthocybium solandri, Caranx hippos, Pagellus bellottii, Trichiurus lepturus, etc. and cephalopods such as, L. vulgaris, $T$. danae, Eucleoteuthis luminosa, Histioteuthis atlantica, Eucleoteuthis luminosa, Chiroteuthis veranyi, were of little importance because of their low specific abundance and occurrence (Fig 4, lower left).

\subsection{Discussion}

The present study addresses food preferences, feeding strategy, trophic ecology and dietary overlap between sexes, size groups and seasons of silky shark in waters off Côte d'Ivoire. The relatively high percentage of empty stomachs $(38.49 \%)$ recorded in this study is common to most shark species $[25,7]$ as some sharks may regurgitate their food upon being captured [26] and some prey may be digested between capture and sampling. A high incidence of empty stomachs may also reflect a long time between capture and examination $[27,28,29]$. According to [27], this high incidence of empty stomachs largely depends on fishing gear. Our study showed that the duration of the tide was 4-5 days and silky shark was caught using baited hooks to attract sharks with empty stomachs which cause high stress at the time of capture, often resulting in the regurgitation (13.92\%) of stomach contents. This may partly explain the large number of empty stomachs. Moreover, fishing takes place at night, when most of their feeding occurs; this may result in a higher frequency of empty stomachs [28].

Most of fish were encountered in a state of intermediate or advanced digestion (states 2 and 3 ), while cephalopods showed mostly a state of advanced digestion (state 4). The states of prey digestion observed here suggest that this species feed constantly in the area. This behaviour has been observed in coastal regions of the Mexican Pacific [30] and in the equatorial, eastern and mid-eastern Pacific Ocean [9].

The stomach content analysis in our study clearly reflects the importance of teleost fishes as an important food item in the diet of silky shark. The most important prey species were Scombridae family represented by K. pelamis (33.19 \%IRI) and $T$. albacares $(60.65 \% \mathrm{IRI})$, making them piscivorous. This is probably associated with the active swimming up to $3000 \mathrm{~km}$ [31] and aggressive of the species, which allows it to capture prey with high locomotion [3]. Cephalopod species, namely $L$. vulgaris, $T$. danae, E. luminosa, $H$. atlantica and $E$. luminosa were rare or incidental food. The findings of the current study align well with those of [10] in Western Indian Ocean who found that silky shark ate mainly teleost fishes, principally members of Scombridae and Carangidae families. However, this observation is in contrast with observations made elsewhere in the world. In Colombia waters and Pacific Ocean, the main prey includes members of the Scombridae and Coryphaenidae families, the coastal cephalopod Loligo sp., a small percentage of crustaceans (Euphylax robustus) and sea turtles (Chelonia mydas) $[32,9,33]$. In near-shore areas off Mexico, [7] reported that silky shark eats mainly red crabs (Pleuroncodes planipes), chub mackerel (Scomber japonicus) and Humboldt squid (D. gigas). Food preference of predatory fish is complex and influenced by many factors, such as available prey and mobility, prey abundance, prey energy content, prey size selection, and seasonal changes $[34,35]$. In view of the foregoing, silky shark can adapt its diet to the availability of food resources, which change in space and time. [36] reported that when food is abundant, sharks behave as selective feeders, maximizing the energy consumed. When food is limited, sharks are generally opportunistic feeders, able to use a wide variety of prey from different habitats throughout the year. The difference in diet of this species could also depend on the physiological stage of the fish, as juveniles are more frequent in areas near the coast, where they consume abundant and easy (e.g. epipelagic crustaceans) prey to save energy during capture; while adults are in oceanic waters feeding on big prey such as tuna, which supply more energy. Although the individuals captured in this study are mainly juveniles, their diet is composed of prey from oceanic waters (for example tuna) because artisanal canoes in Côte d'Ivoire make their catches in oceanic areas. The preys consumed by silky shark were classified as epipelagic fishes (e.g. $T$. albacares and $K$. pelamis) and benthopelagic (e.g. L. vulgaris and $T$. danae), which are characterized by being distributed at 0-500 $\mathrm{m}$ and $385-395 \mathrm{~m}$ depth, providing further evidence that this species undertakes vertical migrations in the water 
column. [37] reported that silky shark dived to depths greater than $300 \mathrm{~m}$, with a maximum recorded depth of $1112 \mathrm{~m}$.

In this study, no difference was found in the diet of C. falciformis, indicating that males and females feed on similar prey species in the same area, or males and females use the same feeding location. On the other hand, even if the main prey in diets were similar in both seasons, prey diversity was highest in cold season and the proportions of teleost fishes decreased slightly in favour of cephalopods during warm season. Silky shark feeding patterns indicated that this species has a broad trophic niche, suggesting that they make use of a variety of available resources. Some studies reported that food preference of predatory fish is complex and influenced by factors, such as available prey and mobility, prey abundance, prey energy content, prey size selection, and seasonal changes $[38,39]$. When food is abundant, sharks behave as selective feeders, maximizing the energy consumed. In contrast, when food is limited, sharks are generally opportunistic feeders, able to use a wide variety of prey from different habitats throughout the year [40]. Based on the

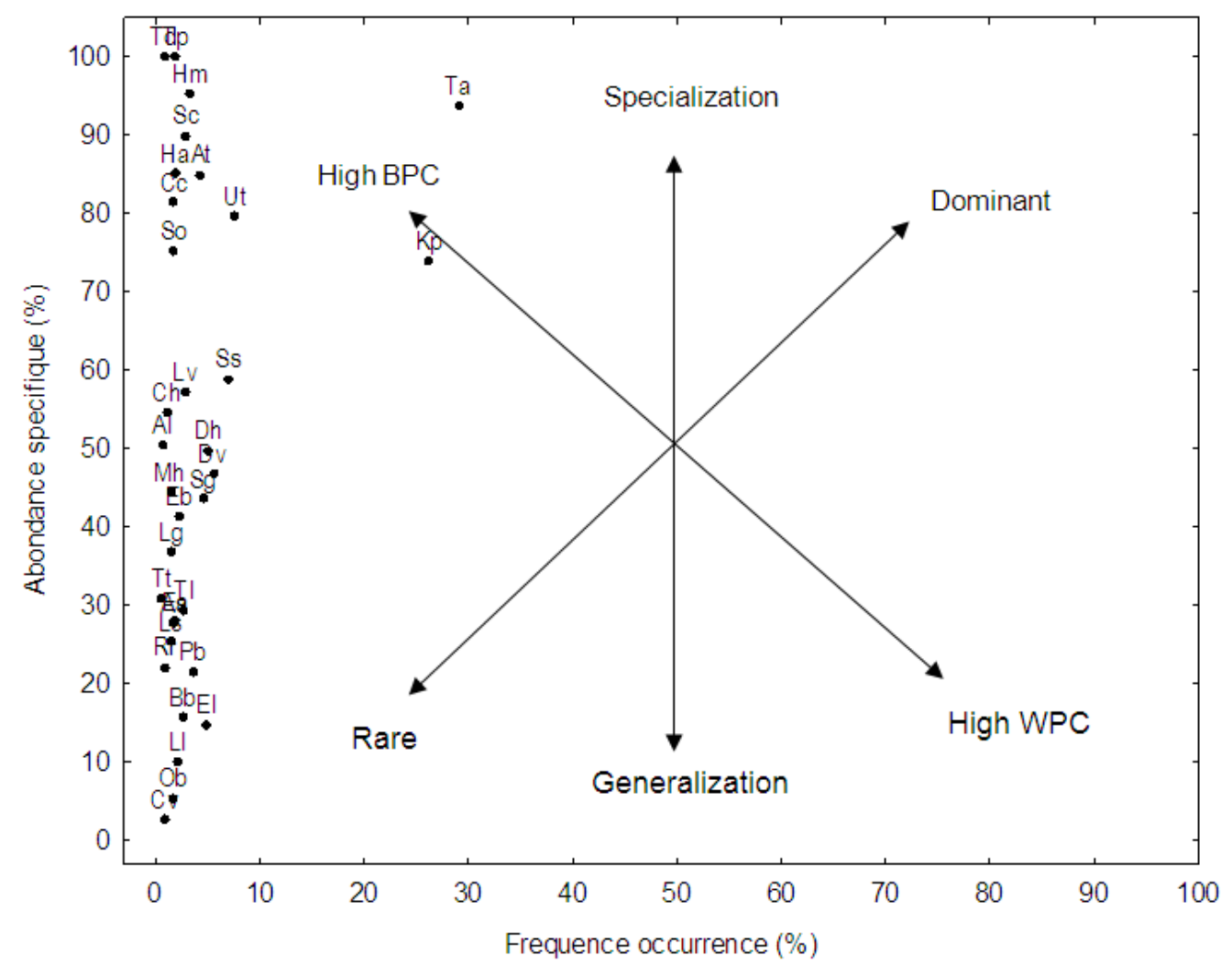

Fig. 4. Prey-specific abundance plotted against frequency of occurrence of prey species. Explanatory axes (a) for foraging Patterns are those of [24] as modified from [23]. The two diagonal axes represent the importance of prey (dominant vs. rare) and the contribution to the niche width (high between-phenotype vs. high within-phenotype contribution); The vertical axis defines the predator feeding strategy (specialist vs. generalist)

$A l=$ Ancistrocherus lesueuri; $A s=$ Acanthocybium solandri; $A t=$ Auxis thazard; $C h=$ Caranx hippos; $C r=C a r a n x$ crysos; $\mathrm{Cv}=$ Chiroteuthis veranyi; $\mathrm{Dh}=$ Diodon holocanthus; $\mathrm{Dv}=$ Dactylopterus volitans; $\mathrm{Ea}=$ Euthynnus alletteratus; $E b$ = Elagatis bipinnulata; $E l=$ Eucleoteuthis luminosa; $\mathrm{Ha}=$ Histioteuthis atlantica; $\mathrm{Hm}=$ Histioteuthis miranda; $K p=$ Katsuwonus pelamis; $L g=$ Lepidoteuthis grimaldii; $L$ I =Lagocephalus lagocephalus; $L s=$ Lobotes surinamensis; $L v=$ Loligo vulgaris; $M h=$ Martialia hyadesi; Ob =Onychoteuthis banksii; $P b=$ Pagellus bellottii; Ss = Sarda sarda; Sc = Seriola carpenteri; Sg = Sphyraena guachancho; So = Sepia officinalis; $T a=$ Thunnus albacares; $T d=$ Taningia danae; $T I=$ Trichiurus lepturus; $T p=$ Teuthowenia pellucida; $\mathrm{Ut}=$ Undetermined tuna 
Amundsen graphical analysis, C. falciformis is considered as a selective or specialist predator, ingesting a wide variety of prey types. This is consistent with [41], [7] and [9], who considered C. falciformis as a specialist predator, because although consuming many preys, some preys are more important in diet following to sexes and seasons. The classification of $C$. falciformis as a specialist predator elsewhere is most likely due to the local abundance and availability of prey species [9] and suggests that this species indeed fulfil the role of generalist predators in the Gulf of Tehuantepec. [9] examining a large number of stomachs from eastern Pacific Ocean concluded that it is indeed an opportunistic feeder in this region.

\section{CONCLUSION}

The information presented here serves as a strong base for increasing our understanding of the trophic ecology of silky shark found in waters off Côte d'lvoire. Diet consisted mainly of $T$. albacares and $K$. pelamis, the proportions of which varied according to size and marine season. The silky shark $C$. falciformis is considered to be a specialist predator, ingesting a wide variety of prey types which seems to be associated with prey availability in the area.

\section{DATA AVAILABILITY STATEMENT}

The data that support the findings of this study are available on reasonable request from the corresponding author.

\section{ACKNOWLEDGMENTS}

We thank the Oceanological Research Center which provided us with the equipment and products for various manipulations. We are grateful to the artisanal fishermen and sellers of the harbour of Abidjan who kindly brought us the catches.

\section{COMPETING INTERESTS}

Authors have declared that no competing interests exist.

\section{REFERENCES}

1. Heithaus MR, Frid A, Wirsing AJ, Worm B. Predicting ecological consequences of marine top predator declines. Trends in Ecology and Evolution. 2008;23(4):202210.
2. Ferretti F, Worm B, Britten GL, Heithaus MR \& Lotze HK. Patterns and ecosystem consequences of shark declines in the ocean. Ecology Letters. 2010;13(8):10551071

3. Bonfil R. "The biology and ecology of the silky shark, Carcharhinus falciformis," in Sharks of the Open Ocean: Biology, Fisheries and Conservation, eds M. D. Camhi, E. K. Pikitch, and E. A. Babcock (Hoboken, NJ: Wiey). 2008;114-127.

4. Campana SE, Joyce W, Manning MJ Bycatch and discard mortality in commercially caught blue sharks Prionace glauca assessed using archival satellite pop-up tags. Marine Ecology Progress Series. 2009;387:241-253.

5. Watson JT, Essington TE, Lennert-cody CE, Hall MA. Trade-offs in the design of fishery closures: Management of silky shark bycatch in the Eastern Pacific Ocean tuna fishery. Conservation Biology. 2008;23(3):626-635.

6. Bizzarro JJ, Yoklavich MM, Wakefield WW. Diet composition and foraging ecology of U.S. Pacific Coast ground fishes with applications for fisheries management. Environmental Biology of Fishes. 2017;100(4):375-393.

7. Cabrera Chávez-Costa A, Galván-Magaña $F$, Escobar-Sánchez O. Food habits of the silky shark Carcharhinus falciformis (Müller \& Henle 1839) off the western coast of Baja California Sur, Mexico. Journal of Applied Ichthyology. 2010;26:499-503.

8. Acuna E. \& Villarroel CJ. Feeding habits of two deep-sea sharks from central-northern Chile: hooktooth dogfish Aculeola nigra (Etmopteridae) and dusky catshark Bythalaelurus canescens (Scyliorhinidae). Revista de Biología Marina y Oceanografía. 2010;45(S1)737-743

9. Duffy LM, Olson RJ, Lennert-Cody CE, Galván-Magaña $F$, Bocanegra-Castillo $N$, Ferretti F, Worm B, Britten GL, Heithaus MR, Lotze HK. Patterns and ecosystem consequences of shark declines in the ocean. Ecology Letters. 2010;13(8):10551071.

10. Filmalter JD, Cowley PD, Potier M, Ménard F, Smale MJ, Cherel Y, Dagorn L. Feeding ecology of silky sharks Carcharhinus falciformis associated with floating objects in the western Indian Ocean. Journal of Fish Biology. 2016;90(4):1321-1337.

11. Flores-martinez Al, Torres-rojas EY, Galván-magaña F, Ramos-miranda J. Diet 
comparison between silky sharks (Carcharhinus falciformis) and scalloped hammerhead sharks (Sphyrna lewini) off the south-west coast of Mexico. Journal of the Marine Biological Association of the United Kingdom. 2016;97:337-345.

12. Blache J, Cadenat J, Stauch A. Clés de détermination des familles de poissons téléostéens signalés dans le golfe de Guinée. In faune tropicale: Clé de determination des poissons de mer signalés dans l'Atlantique oriental (entre le 20è parallèle Nord et le 15è parallèle Sud). ORSTOM. Paris; 1970.

13. Carpenter KE, De Angelis N. The living marine are sources of the Eastern Central Atlantic. Volume 3: Bony fishes part 1 (Elopiformes to Scorpaeniformes). FAO Species Identification Guide for Fishery Purposes, Rome; 2016.

14. Iglésias SP. Handbook of the marine fishes of Europe and adjacent waters. A natural classification based on collection specimens, with DNA barcodes and standardized photographs; 2014.

15. Lu CC \& Ickeringill R. Cephalopod beak identification and biomass estimation techniques: tools for dietary studies of southern Australian finfishes. Museum Victoria Science Reports. 2002;6:1-65.

16. Xavier JC, Cherel Y. Cephalopod beak guide for the southern ocean. British Antarctic Survey, Cambridge. UK. 2009.

17. Clarke MR. A Handbook for the Identification of Cephalopod Beaks. Oxford: Clarendon Press; 1986.

18. Pinkas L, Oliphant MS, Iverson ILK. Food habits of albacore, bluefin tuna and bonito in California waters of the Pacific Ocean. State of California the resources agency department of fish and game. California Department of Fish and Game. 1971;152: 1-105.

19. Cortés E. A critical review of methods of studying fish feeding based on analysis of stomach contents: application to elasmobranch fishes. Canadian Journal of Fisheries and Aquatic Sciences. 1997;54: 726-738.

20. Rosecchi E, Nouaze Y. Comparaison de cinq indices alimentaires utilisés dans l'analyse des contenus stomacaux. Rev. Trav. Inst. Pêches Marit. 1987;49:111-123.

21. Morisita M. Measuring of the dispersion and analysis of distribution patterns. Memories of the Faculty of Science,
Kyushu University. Series E. Biology. 1959;2:215-235.

22. Hyslop EJ. Stomach contents analysis, a review of methods and their application. Journal of Fish Biology. 1980;17:411-429.

23. Amundsen PA, Gabler HM, Staldvik FJ. A new approach to graphical analysis of feeding strategy from stomach contents data modification of the Costello method. Norway Journal of Fish Biology. 1996;48: 607-614.

24. Costello MJ. "Predator feeding strategy and prey importance: a new graphical analysis." J.Fish Biol. 1990;36:261-263.

25. Joyce WN, Campana SE, Natanson LJ, Kohler NE, Pratt HL, Jensen CF. Analysis of stomach contents of the porbeagle shark (Lamna nasus Bonnaterre) in the northwest Atlantic. Ices Journal of Marine Science. 2002;59:1263-1269.

26. Stevens JD. Stomach contents of the blue shark (Prionace glauca) off south-west England. Journal of the Marine Biological Association of the United Kingdom. 1973;53:357-361

27. Hazin FHV, Couto AA, Kihara K, Otsuka K, Ishino M, Boeckman CE, Leal EC. Reproduction of the blue shark Prionace glauca in the south-western equatorial Atlantic Ocean. Fisheries Science. 1994;60(5):487-491.

28. Henerdson AC, Flannery K, Dunne J. Observation on the biology and ecology of the blue shark in the nord-est Atlantic. Jounal of Fish Biology. 2000;58:13471358.

29. McCord ME, Campana SEA quantitative assessment of the diet of the blue shark (Prionace glauca) off Nova Scotia, Canada. Journal of Northwest Atlantic Fishery Science. 2003;32:57-63.

30. Torres-Rojas YE, Herna ndez-Herrera $A$, Galván-Magaña $F$, Alatorre-Ramirez VG. Stomach content analysis of juvenile scalloped hammerhead shark Sphyrna lewini captured off the coast of Mazatla n, Mexico. Aquatic Ecology. 2009;44:301308.

31. Schaefer KM, Fuller DW, Aires-Da-Silva A, Carvajal JM, Martínez-Ortiz J, Hutchinson MR. Postrelease survival of silky sharks (Carcharhinus falciformis) following capture by longline fishing vessels in the equatorial eastern Pacific Ocean. Bull. Mar. Sci. 2019;95:355-369.

DOI: $10.5343 / \mathrm{bms} .2018 .0052$ 
32. Acevedo A. Lista de mamíferos marinos en Golfo Dulce e Isla del Coco, Costa Rica. Revista de Biología Tropical. 1996;44: 933-934.

33. Wetherbee B.M, Gruber SH, Cortes E. "Diet, Feeding Habits, Digestion, and Consumption in Sharks, with Special Reference to the Lemon Shark, Negaprion brevirostris." Elasmobranchs as Living Resources: Advances in the Biology, Ecology, Systematics, and the Status of the Fisheries (H.L. Pratt Jr., S.H. Gruber, and T. Taniuchi, eds.) NOAA Technical Report. 1990:90:29-47.

34. Hart PJB, Ison S. The influence of prey size and abundance, and individual phenotype on prey choice by the threespined stickleback, Gasterosteus aculeatus L. Journal of Fish Biology. 1991;38:359-372.

35. Estupiñán-Montaño $C$, Pacheco-Triviño $F$, Cedeño-Figueroa LG, Galván-Magaña F, Estupiñán-Ortiz JF. Diet of three shark species in the Ecuadorian Pacific, Carcharhinus falciformis, Carcharhinus limbatus, and Nasolamia velox. Journal of the Marine Biological Association of the United Kingdom. 2017;1-9.

36. Stergiou KI, Fourtouni $\mathrm{H}$. Food habits, ontogenetic diet shift and selectivity in Zeus faber Linnaeus, 1758. Journal of Fish Biology. 1991;39(4):589-603.
37. Curnick DJ, Andrzejaczek S, Jacoby DMP, Coffey DM, Carlisle AB, Chapple TK, Ferretti F, Schallert RJ, White $\mathrm{T}$, Block BA, Koldewey $\mathrm{HJ}$ and Collen B. Behavior and Ecology of Silky Sharks Around the Chagos Archipelago and Evidence of Indian Ocean Wide Movement. Front. Mar. Sci. 2020;7: 1-18.

38. Hart PJB, Ison S. The influence of prey size and abundance, and individual phenotype on prey choice by the threespined stickleback, Gasterosteus aculeatus L. Journal of Fish Biology. 1991;38:359-372.

39. Fall J, Fiksen $\varnothing$. No room for dessert: A mechanistic model of prey selection in gut-limited predatory fish. Fish and Fisheries. 2019;00:1-17.

40. Wetherbee BM, Crow GL, Lowe CG. Biology of the galapagos shark, Carcharhinus galapagensis in Hawaii. Environmental Biology of Fishes. 1990;45: 299-310.

41. Barranco SLM. Food habits and trophic level from the silky shark, Carcharhinus falciformis, Mûller \& Henle 1841 (Elasmobranchii: Carcharhinidae) in the Gulf of Tehuantepec, México using stomach contents and stable isotopes of $\mathrm{d} 13 \mathrm{C}$ and $\mathrm{d} 15 \mathrm{~N}$. Master thesis, Universidad del Mar, Oaxaca; 2008.

(c) 2021 N'Gouan et al.; This is an Open Access article distributed under the terms of the Creative Commons Attribution License (http://creativecommons.org/licenses/by/4.0), which permits unrestricted use, distribution, and reproduction in any medium, provided the original work is properly cited.

Peer-review history:

The peer review history for this paper can be accessed here: https://www.sdiarticle4.com/review-history/71510 